\title{
Retraction: Revisiting hydrocephalus as a model to study brain resilience
}

\author{
Human Neuroscience Editorial Office *
}

\section{OPEN ACCESS}

Approved by:

Hauke R. Heekeren,

Free University of Berlin, Germany

${ }^{*}$ Correspondence:

Human Neuroscience Editorial Office humanneuroscience.editorial.office@

frontiersin.org

Received: 11 July 2016

Accepted: 11 July 2016

Published: 22 July 2016

Citation:

Human Neuroscience Editorial Office

(2016) Retraction: Revisiting

hydrocephalus as a model to study

brain resilience.

Front. Hum. Neurosci. 10:375.

doi: 10.3389/fnhum.2016.00375

\section{A retraction of the Mini Review Article}

Revisiting hydrocephalus as a model to study brain resilience

by de Oliveira, M. F., Pinto, F. C. G., Nishikuni, K., Botelho, R. V., Lima, A. M., and Rotta, J. M. (2012). Front. Hum. Neurosci. 5:181. doi: 10.3389/fnhum.2011.00181

The journal retracts the 6 January 2012 article cited above. Following a series of concerns regarding the origin of images in this article, Frontiers conducted an investigation. The results of this investigation determined that, as these images formed an integral part of the article and did not originate in the authors' laboratories and were not duly attributed, the article does not meet the scientific criteria of the journal. This retraction was approved by the Specialty Chief Editors of Frontiers in Human Neuroscience. The authors concur with the retraction and sincerely regret any inconvenience this may have caused to the reviewers, editors, and readers of Frontiers in Human Neuroscience.

Copyright $\odot 2016$ Human Neuroscience Editorial Office. This is an open-access article distributed under the terms of the Creative Commons Attribution License (CC BY). The use, distribution or reproduction in other forums is permitted, provided the original author(s) or licensor are credited and that the original publication in this journal is cited, in accordance with accepted academic practice. No use, distribution or reproduction is permitted which does not comply with these terms. 